\title{
Sosialisasi Perawatan dan Pembuatan Face shield bagi Tenaga Kesehatan
}

\author{
Nuzulia Khoiriyah1, Sri Mulyono², Bagus Satrio Waluyo Poetro² \\ 'DepartemenTeknik Industri, '2Departemen Teknik Informatika, Fakultas Teknologi Industri \\ Universitas Islam Sultan Agung, Jl. Kaligawe KM 4 Semarang, Indonesia
}

\section{ARTICLE INFO}

Received: 2020-11-02

Revised: 2021-02-26

Accepted: 2021-05-07

Keywords:

COVID-19, Face shield, Personal protective equipment, Printer 3D

\section{ABSTRACT}

Face shield is one of the important PPE (Personal Protective Equipment) for health workers in health services in the era of the COVID-19 pandemic as it is today. The limited number of face shield will certainly hamper the health services provided by the hospital. This Community Services activity was carried out at RSI Sultan Agung and RSIGM Sultan Agung to provide training on making face shield independently and also maintenance, so that face shield is more durable and not easily damaged. The tool used is a 3D printer which is easy to operate. 3D Printing technology will produce solid objects, and not like printing a sheet of paper on a printer that is commonly used. Design 3D models using CAD software. This activity was attended by 80 participants. $91.25 \%$ of participants are interested in making their own face shields as an effort to meet the need for face shields From the Community Services activities, around 100 face shields were produced which were handed over to the hospital.
\end{abstract}

(C)2021 Published by University of Merdeka Malang. This is an open access article distributed under the CC BY-SA 4.0 license (https://creativecommons.org/licenses/by-sa/4.0/)

How to cite: Khoiriyah, N., Mulyono, S., \& Poetro, B. S. W. (2021). Sosialisasi Perawatan dan Pembuatan Face shield bagi Tenaga Kesehatan. Abdimas: Jurnal Pengabdian Masyarakat Universitas Merdeka Malang, 6(3), 448-455 https://doi.org/10.26905/abdimas.v6i3.5288

\section{PENDAHULUAN}

COVID-19 adalah penyakit yang disebabkan oleh virus corona. Penyakit ini telah menjadi pandemi global yang telah menginfeksi jutaan manusia dari ratusan negara serta menyebabkan ratusan ribu orang telah meninggal akibat virus ini (Sipahutar \& Eryando 2020). Pandemi COVID-19 ini menjadi kekhawatiran seluruh umat manusia di dunia. Pasalnya, penyebaran COVID-19 terhitung sangat cepat lantaran dapat menyebar melalui kontak jarak dekat baik yang melibatkan sentuhan fisik secara langsung maupun tidak. Bahkan penularan virus ini bisa melalui udara atau droplet dari penderita COVID-19 (Chu et al., 2020) 
Meningkatnya kasus COVID-19 tentu harus mendapat perhatian yang lebih serius lagi sehingga kasus ini bisa dicegah penyebarannya. Salah satu yang dilakukan yaitu mempersiapkan seluruh fasilitas kesehatan khususnya rumah sakit. Termasuk kelengkapan bagi tenaga medis sebagai garda terdepan dalam pelayanan kesehatan (Pesulima \& Hetharie 2020). Risiko tenaga medis tertular COVID-19 sangat besar bahkan banyak tenaga medis yang gugur akibat terpapar virus COVID-19. Tenaga Medis haruslah dibekali dengan peralatan perlindungan diri yang lengkap (Alzunitan et al., 2021; Pesulima \& Hetharie 2020)

Dalam kondisi normal belum semua rumah sakit di Indonesia memiliki kualitas dan kuantitas yang sama karena berbagai keterbatasannya. Bahkan perbandingan jumlah tenaga kesehatan seperti dokter atau jumlah tempat tidur belum mencukupi jumlahnya dibandingkan dengan jumlah penduduk. Sangat berbahaya jika rumah sakit tidak mampu melayani seluruh penderita COVID-19 karena kasus terus bertambah. Karena itu seluruh rumah sakit, negeri maupun swasta harus siap menghadapi wabah ini. Kesiapan tersebut bisa dilihat dari berbagai aspek bukan hanya dari satu sisi. Pertama, kesiapan sumber daya manusia yang sangat vital. Setiap rumah sakit harus betul-betul memastikan sumber daya manusia yang dimiliki seperti dokter, perawat maupun tenaga non medis lainnya. Kesiapan dilihat dari jumlah sumber daya manusia yang dimiliki, kesiapan skill, maupun kesiapan fisik dan mental.

Kesiapan kedua adalah kesiapan logistik rumah sakit berupa alat-alat medis, alat pelindung diri, ruang isolasi, maupun obat-obatan. Keberadaan logistik sangat penting karena sebagai penunjang utama bagi para tenaga kesehatan di rumah sakit. Saat ini dengan melonjaknya kasus COVID-19, fasilitas peralatan yang ada di rumah sakit menjadi terbatas (Mudayana, 2020). Hal tersebut juga dialami oleh Rumah Sakit Islam (RSI) Sultan Agung Semarang dan juga Rumah Sakit Islam Gigi Mulut (RSIGM) Sultan Agung. Alat Pelindung Diri (APD) yang dibutuhkan tenaga medis atau tenaga kesehatan (nakes) masih terbatas, terutama pada jumlah face shield atau alat pelindung wajah / tameng wajah.

Di masa COVID-19, pelindung wajah ini penting untuk melindungi tenaga medis pada saat berinteraksi dengan pasien, untuk melindungi wajah dari paparan virus pada saat sedang berhadapan dengan pasien (Roberge 2016). Sebagai informasi tambahan, masa inkubasi virus COVID-19 secara penelitian ilmiah adalah 14 hari (Elias et al., 2021), dengan masa inkubasi virus yang beragam, biasanya 5-6 hari tergantung kondisi fisik dari tiap manusia.

Lama masa inkubasi COVID-19 membuat sulit sekali untuk mendeteksi apakah seseorang telah terpapar dan membawa virus dalam tubuhnya. Padahal setiap hari tenaga medis dituntut untuk bertemu secara langsung pada masyarakat guna memberikan pelayanan kesehatan tanpa mengetahui apakah pasien yang ditangani membawa virus COVID-19 atau bersih dari virus tersebut. Apalagi saat ini Kota Semarang masuk pada Zona merah pandemi COVID-19.

Keterbatasan APD salah satunya face shield pasti menimbulkan kekhawatiran tenaga medis dalam bekerja, rasa tidak aman, sehingga akan mengurangi konsentrasi dalam pekerjaannya. Karena salah satu fungsi face shield sebagai alat pelindung wajah yang mampu meminimalkan paparan droplet atau virus dari orang lain (Theopilus et al., 2020; Wati et al., 2020). Face shield dapat melindungi individu 
ABDIMAS: Jurnal Pengabdian Masyarakat Universitas Merdeka Malang Volume 6, No. 3, August 2021: 448-455

penggunanya dari terpapar infeksi (Duarsa et al., 2020; Nugroho et al., 2020). Ketiadaan alat tersebut akan sangat berpengaruh terhadap keselamatan dan kelancaran tenaga medis dalam memberikan pelayanan kesehatan pada masyarakat.

Tenaga medis yang ada di RSI Sultan Agung Semarang dan Rumah Sakit Islam Gigi Mulut (RSIGM) Sultan Agung membutuhkan face shield dalam rangka pemenuhan APD yang lengkap guna melakukan pelayanan pada masyarakat. Rumah sakit tidak sepenuhnya mampu terus menerus memenuhi kebutuhan face shield bagi tenaga medis karena jumlah tenaga medis yang cukup banyak. Selain jumlah yang cukup banyak, hal lain yang membuat kebutuhan face shield cukup tinggi dikarenakan face shield merupakan peralatan yang tidak dapat digunakan dalam waktu lama karena alat tersebut riskan rusak karena hampir setiap saat digunakan dan jarang dilakukan perawatan pada alat tersebut. Oleh karena itu untuk membantu pihak rumah sakit dan juga tenaga medis dalam memenuhi kebutuhan face shield secara mandiri, agar tenaga medis tetap dapat menggunakan alat tersebut saat bekerja untuk peerlindungan wajah dari paparan virus, maka kegiatan pengabdian masyarakat dalam program sosialisasi perawatan dan pembuatan face shield secara mandiri bagi tenaga medis di RSI Sultan Agung Semarang dan Rumah Sakit Islam Gigi Mulut (RSIGM) Sultan Agung dilaksanakan. Harapannya pihak rumah sakit ataupun tenaga medis mampu untuk memproduksi face shield secara mandiri agar tidak tergantung pada stok yang ada di pusat logistik rumah sakit. Selain itu dengan pengadaan face shield secara mandiri maka dari segi pendanaan terhitung lebih ekonomis.

\section{METODE}

Pelaksanaan program pengabdian masyarakat untuk tenaga medis yang ada di Rumah Sakit Islam (RSI) Sultan Agung dan Rumah Sakit Gigi Mulut (RSIGM) Sultan Agung ini meliputi beberapa tahapan sebagai berikut.

\section{Tahap informasional}

Pada tahap ini dilakukan proses pencarian data terkait kebutuhan APD yang sangat dibutuhkan oleh tenaga medis di lingkungan RSI Sultan Agung dan Rumah Sakit Islam Gigi Mulut (RSIGM) Sultan Agung. Hasil temuan menunjukkan bahwa salah satu kebutuhan APD yang perlu dipenuhi dan mampu diupayakan secara mandiri oleh tenaga Medis mdalah face shield.

\section{Tahap literasi, persiapan alat dan penyiapan bahan baku}

Pada tahap ini dilakukan proses pencarian alat produksi yang cocok dan tepat yang dapat digunakan untuk mendukung proses pembuatan face shield yang mudah dan dapat dilakukan secara mandiri tidak harus hasil produksi pabrikan (Khurana et al., 2020). Beberapa alat kemudian dibandingkan. Pada tahap ini dilakukan proses pengumpulan data terkait dengan alat yang tersedia di pasaran dan mempelajari bagaimana sistem kerja alat yang digunakan untuk memproduksi face shield secara mandiri. Setelah 
didapatkan alat yang tepat, maka selanjutnya adalah proses pembelian atau penyediaan alat, persiapan operasionalisasi alat dan penyediaan bahan baku pembuat face shield.

Secara struktur komponen face shield adalah: visor (tameng transparan), frame (rangka) dan suspension system (Roberge 2016). Bagian rangka bisa terbuat dari material plastik (Roberge 2016) (Theopilus et al., 2020; Roberge, 2016). Terdapat juga frame yang berbentuk kacamata. Secara umum bagian visor terbuat dari plastik transparan seperti polycarbonate, propionate, acetate, PVC, dan PETG dengan ketebalan yang bervariasi. Bagian visor ini dipasang pada rangka menggunakan pengikat yang terbuat dari baut, kancing pin atau menempel pada rangka secara langsung. Bagian visor ini ada yang dapat dinaik turunkan tanpa perlu melepas frame dari kepala.

\section{Tahap pembuatan alat (face shield)}

Tahap ini adalah tahap produksi pembuatan face shield baik kerangka face shield maupun tutup depan wajah. Peralatan yang digunakan dalam tahap ini adalah printer 3D. 3D Printing adalah salah satu teknologi terbaru dunia percetakan, dimana teknologi percetakan 3D ini akan menjadi salah satu tren teknologi dimasa depan. Teknologi 3D Printing akan menghasilkan benda padat, dan bukan seperti mencetak selembar kertas pada printer yang sudah biasa digunakan (Hakim et al., 2019). Printer 3D ini akan melengkapi teknologi printer 2D yang sudah lama kita gunakan sebagai alat cetak yang outputnya berupa lembaran 2 dimensi (Seprianto \& Wilza, 2017). Edukasi proses pembuatan face shield secara mandiri juga dilakukan pada tenaga medis yang ikut pelatihan.

\section{Tahap penyerahan alat (face shield)}

Tahap penyerahan face shield kepada tenaga medis dilakukan secara bertahap, karena alat yang digunakan tidak mampu memproduksi dalam jumlah banyak dan waktu yang cepat. Kecepatan pemenuhan kebutuhan akan face shield mengikuti kemampuan dari alat dalam memproduksi rangka face shield. Penyerahan face shield dilakukan dari pelaksana program kepada pihak RSI Sultan Agung dan Rumah Sakit Islam Gigi Mulut (RSIGM) Sultan Agung yang kemudian diserahkan kepada tenaga medis.

\section{Tahap sosialisasi}

Pada tahap ini dilakukan sosialisasi simulasi pembuatan face shield, penggunaan face shield, edukasi pemasangan mika (penutup wajah) dan perawatan face shield secara mandiri pada tenaga medis di lingkungan RSI Sultan Agung dan RSIGM Sultan Agung. Hal ini dilakukan agar kegiatan ini tidak berhenti saat pelatihan saja tapi tetap dipraktekkan dan ditindaklanjuti oleh tenaga medis sehingga kegiatan ini mampu memberikan kemanfaatan tidak hanya bagi pihak rumah sakit namun juga bagi individu tenaga medis. 
ABDIMAS: Jurnal Pengabdian Masyarakat Universitas Merdeka Malang

Volume 6, No. 3, August 2021: 448-455

\section{HASIL DAN PEMBAHASAN}

\section{Tahap informasional}

Pada penyebaran kuisioneryang dilakukan terhadap tenaga medis/tenaga kesehatan di lingkungan RSI dan RSIGM Sultan Agung menunjukkan bahwa: (1) 98,75 \% responden nakes was-was dan khawatir jika dalam bertugas jika tidak menggunakan face shield; dan (2) 98,75\% responden nakes merasa lebih aman jika menggunakan face shield dalam bertugas. Dari jawaban yang diberikan responden terkait kebutuhan face shield, menunjukkan bahwa kebutuhan nakes terhadap APD face shield adalah sangat tinggi.

\section{Tahap literasi, persiapan alat, dan bahan baku}

Teknologi 3D Printing memiliki peluang besar di industri manufaktur, terutama dalam pembuatan produk-produk fleksibel. Teknologi yang digunakan yaitu Fused Deposition Modelling (FDM). Meskipun demikian proses pencetakan filamen dengan teknologi tersebut masih memerlukan studi lebih lanjut. Terdapat beberapa jenis filament fleksibel, yaitu Thermoplastic Elastomer (TPE) dan Thermoplastic polyurethane (TPU) yang digunakan untuk penciptaan produk-produk fleksibel (Pristiansyah et al., 2019).

Pada proses 3D Printing, material yang digunakan adalah PLA atau Poly Lactic Acid. PLA merupakan salah satu jenis plastik polimer yang terbuat dari bahan-bahan yang dapat terurai, seperti tepung jagung, tepung tapioka, atau olahan tebu. Karena terbuat dari bahan yang mudah terurai, PLA ramah lingkungan. Hal inilah yang membuat bahan ini semakin banyak mendapatkan popularitas. PLA dapat menghasilkan cetakan yang kuat dan sangat rapi (Putra \& Sari 2018). Selain PLA, bahan lain yang digunakan sebagai pelengkap adalah filamen PVC, mika yashica, karet elastis, cable ties. Alat-alat lainnya yang digunakan selain printer 3D Anet A8, adalah obeng, kunci [as, kunci L, tang potong dan pembolong kertas

\section{Tahap pembuatan alat (face shield)}

Alur proses pembuatan alat (face shield) yang dilakukan digambarkan pada Gambar 1.

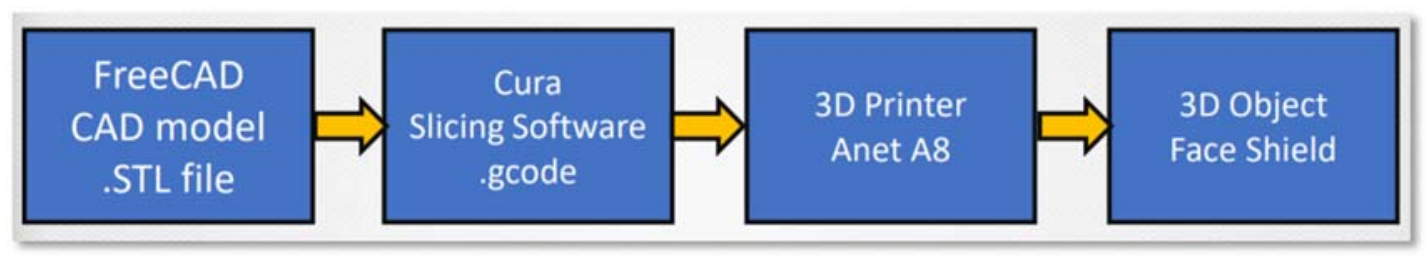

Gambar 1. Proses pembuatan face shield

Adapun spesifikasi alat yang digunakan digambarkan pada Gambar 2. Tampilan desain alat pada program yang digunakan ditunjukkan pada Gambar 3. Gambar 4 adalah kondisi ruang produksi pembuatan alat (face shield). Setelah rangka selesai dicetak, selanjutnya pemasangan mika dan tali pada face shield seperti pada Gambar 5. Adapun bentuk akhir face shield yang dihasilkan ditunjukkan pada Gambar 6 

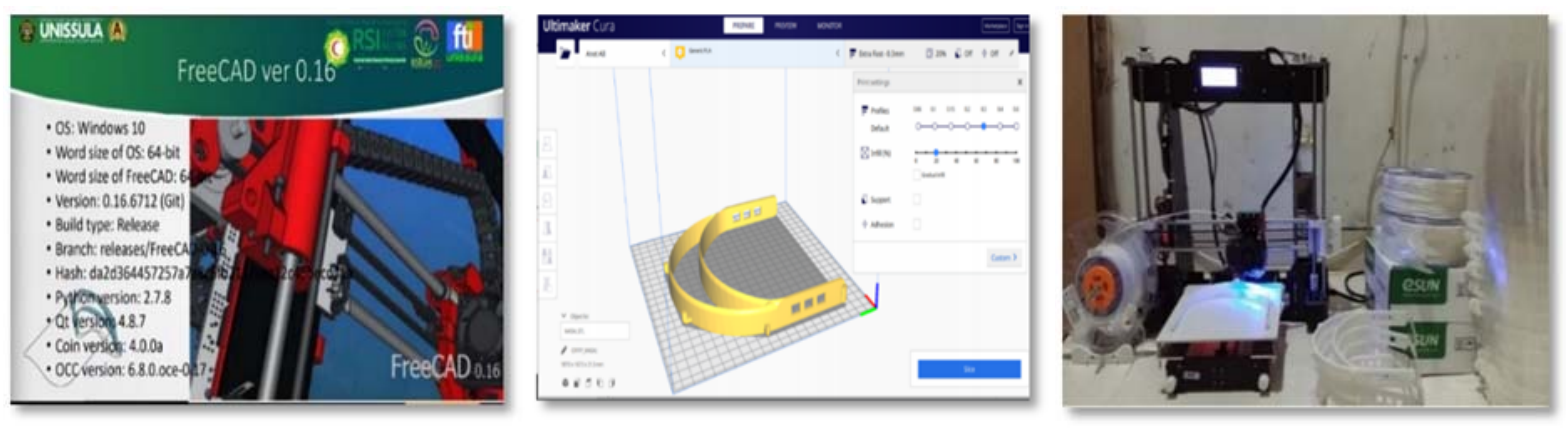

Gambar 2. FreeCAD ver 0.16

Gambar 3. Ultimaker cura 4.4.1

Gambar 4. Proses pencetakaan filamen PVC

Gambar 5. Pemasangan mika dan tali

Gambar 6. Face shield

\section{Tahap penyerahan alat (face shield)}

Tahap penyerahan face shield kepada pihak rumah sakit dilakukan secara bertahap, mengikuti kemampuan dari alat dalam memproduksi rangka face shield. Penyerahan face shield dilakukan dari pelaksana program kepada pihak RSI Sultan Agung dan Rumah Sakit Islam Gigi Mulut (RSIGM) Sultan Agung yang kemudian diserahkan kepada tenaga medis atau tenaga kesehatan (nakes).

Ada beberapa tahap penyerahan face shield pada pihak rumah sakit, yaitu: (1) Tanggal 14 September 2020 sebanyak 30 Face shield (RSI Sultan Agung); (2) Tanggal 25 September 2020 sebanyak 30 Face shield (RSIGM); (3) Tanggal 6 Oktober 2020 sebanyak 30 Face shield (RSIGM); dan (4) Tanggal 13 Oktober 2020 sebanyak 30 Face shield (RSIGM). Gambar 7 dan 8 adalah dokumentasi penyerahan face shield.
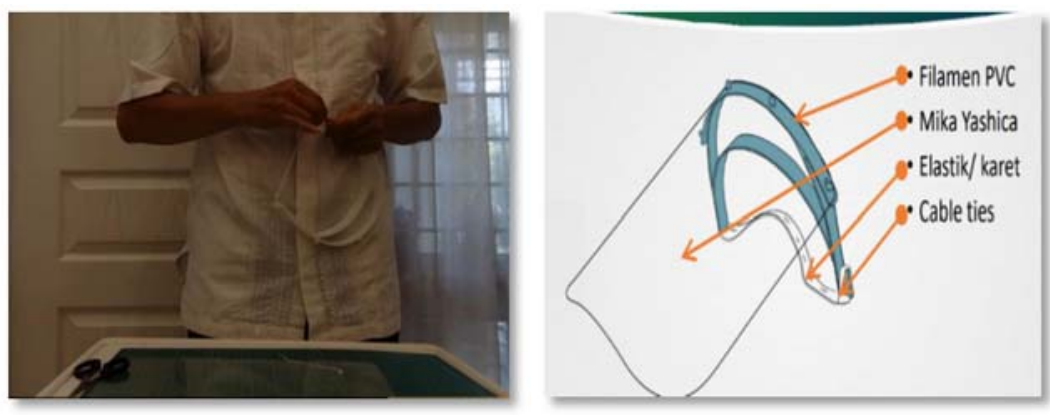

Gambar 7. Penyerahan face shield pada pihak RSI Sultan Agung

Gambar 8. Penyerahan face shield pada pihak RSIGM Sultan Agung

\section{Tahap sosialisasi}

Pada tahap ini dilakukan simulasi pembuatan face shield, penggunaan face shield, edukasi pemasangan mika (penutup wajah) dan perawatan face shield secara mandiri pada tenaga kesehatan di lingkungan RSI Sultan Agung dan RSIGM Sultan Agung. Sosialiasi dan simulasi diikuti oleh 80 peserta 
ABDIMAS: Jurnal Pengabdian Masyarakat Universitas Merdeka Malang

Volume 6, No. 3, August 2021: 448-455

dari kalangan medis dan dilaksanakan secara daring melalui webinar pada tanggal 4 September 2020 dan diberitakan pada media massa yaitu suara merdeka dengan link https://www.suaramerdeka.com/ regional/semarang/239779-bantu-tenaga-medis-tangani-COVID-fti-unissula-produksi-face-shield

Program Pengabdian Masyarakat ini telah mampu membuat lebih dari 100 face shield yang diserahkan pada pihak RSI Sultan Agung dan RSIGM Sultan Agung. Sosialisasi cara membuat face shield secara mandiri dan cara perawatannya juga sudah dilakukan. Dari hasil evaluasi yang dilakukan melalui kuisioner didapatkan data sebagai berikut: (1) 98,75 \% peserta merasa lebih aman jika menggunakan face shield dalam bertugas; (2) 98,75 \% peserta menyatakan bahwa pengetahuan pembuatan face shield secara mandiri penting untuk diketahui; (3) $100 \%$ peserta menyarakan perlu untuk mengetahui cara merawat face shield agar tahan lama dan tetap aman digunakan; (4) 91,25\% peserta tertarik untuk membuat face shield sendiri baik secara mandiri maupun berkelompok; dan (5) $100 \%$ peserta menyatakan program ini memberikan tambahan pengetahuan yang positif.

\section{SIMPULAN DAN SARAN}

Face shield memiliki fungsi sebagai penghalang droplet yg dikeluarkan seseorang saat batuk/ bersin, pelindung dari paparan jarak dekat terhadap partikel virus yg dipancarkan melalui batuk/bersin yang secara signifikan bisa mengurangi paparan inhalasi ke virus influenza/penyakit pernapasan lainnya. Mengingat pentingnya alat tersebut dan juga faktor risiko yang tinggai dari nakes saat bertemu dengan pasien membuat nakes merasa face shield menjadi kebutuhan utama dalam kelengkapan pelayanan medis. Program ini telah mampu memberikan informasi dan pengetahuan pembuatan face shield secara mandiri. Pembuatan face shield secara meandiri ini sangat mudah dan ekonomis untuk dilakukan. Kegiatan ini mampu memberikan manfaat bagi pemenuhan kebutuhan face shield untuk tenaga kesehatan di RSI Sultan Agung dan RSI Gigi Mulut Sultan Agung.

Kegiatan ini hendaklah mampu ditindaklanjuti oleh pihak rumah sakit untuk bisa membuat face shield secara mandiri tanpa harus membeli dari luar, mengingat kebutuhan sumah sakit akan pemenuhan APD face shield bagi nakes sangat banyak.

\section{UCAPAN TERIMA KASIH}

Terima kasih kepada LPPM Universitas Islam Sultan (UNISSULA) yang membiayai kegiatan ini dan kepada RSI Sultan Agung dan RSI Gigi Mulut Sultan Agung sebagai mitra kegiatan pengabdian masyarakat ini.

\section{DAFTAR PUSTAKA}

Chu, D. K., Akl. E. A., Duda. S., Solo, K., Yaacoub, S., Schünemann, H. J., El-harakeh, A. (2020). Physical distancing, face masks, and eye protection to prevent person-to-person transmission of SARSCOV-2 and COVID-19: A systematic review and meta-analysis. The Lancet, 395(10242): 197387. https://doi.org/10.1016/s0140-6736(20)31142-9 
Duarsa, A. B. S., ling, I., Mardiah, A., Karmila, D., \& Wanadiatri, H. (2020). Desain dan pembuatan 1000 face shield sebagai alat pelindung diri dalam mencegah COVID-19. Jurnal Pengabdian Masyarakat Sasambo, 2(1), 140-143.

Elias, C., Sekri, A., Leblanc, P., Cucherat, M., \& Vanhems, P. (2020). Incubation period of COVID-19: A meta-analysis. https://doi.org/10.1016/j.ijid.2021.01.069

Hakim, R., Saputra, I., Utama, G. P., \& Setyoadi, Y. (2019). Pengaruh temperatur nozzle dan base plate pada material PLA terhadap nilai masa jenis dan kekasaran permukaan produk pada mesin Leapfrog Creatr 3D Printer. Jurnal Teknologi dan Riset Terapan (JATRA), 1(1), 1-8.

Khurana, S., Singh, P., Sinha, T. P., Bhoi, S., \& Mathur, P. (2020). Low-cost production of handrubs and face shields in developing countries fighting the COVID19 pandemic. American Journal of Infection Control, 48(6), 726-727. https://doi.org/10.1016/j.ajic.2020.03.016

Mudayana, A. A. (2020, April 1). Kesiapan Rumah Sakit Tangani COVID-19. Suaramerdeka.com. Retrieved from: https://www.suaramerdeka.com/opini/pr-04129932/kesiapan-rumah-sakittangani-COVID19?page=all

Nugroho, C., Ismail, M., Sagoro, G., Maskarai, A., Gozali, M., Asrafi, A., Satoto, S., Saputra, R., Rusdwinanto, C., Sriyanto, S., Prasetyo, N., \& Antartika, M. (2020). Desain dan pembuatan faceshield sebagai alat perlindungan diri penyebaran COVID19. Jurnal Pengabdian Kepada Masyarakat (AbdiMas), 2(1), 1-16. https://doi.org/10.30871/abdimas.v2i1.1995

Pesulima, T. L., \& Hetharie, Y. (2020). Perlindungan hukum terhadap keselamatan kerja bagi tenaga kesehatan akibat pandemi COVID-19. SASI, 26(2), 280. https://doi.org/10.47268/sasi. v26i2.307

Pristiansyah, P., Hasdiansah, H., \& Sugiyarto, S. (2019). Optimasi parameter proses 3D printing FDM terhadap akurasi dimensi menggunakan filament eflex. Manutech: Jurnal Teknologi Manufaktur, 11(01), 33-40. https://doi.org/10.33504/manutech.v11i01.98

Putra, K. S., \& Sari, U. R. (2018). Pemanfaatan teknologi 3d printing dalam proses desain produk gaya hidup. In Seminar Nasional Sistem Informasi dan Teknologi Informasi, 917-922. STMIK Pontianak.

Roberge, R. J. (2016). Face shields for infection control: A review. Journal of Occupational and Environmental Hygiene, 13(4), 235-242. https://doi.org/10.1080/15459624.2015.1095302

Seprianto, D., Wilza, R., \& Iskandar. (2017). Optimasi parameter pada proses pembuatan objek 3D printing dengan teknologi FDM terhadap akurasi geometri. Prosiding. In Seminar Nasional Teknik Industri Universitas Gadjah Mada. November: 37-49. Yogyakarta.

Sipahutar, T., \& Eryando, T. (2020). COVID-19 case fatality rate and detection ability in Indonesia. Kesmas: National Public Health Journal, 15(2), 14-17. https://doi.org/10.21109/kesmas. v15i2.3936

Theopilus, Y., Yogasara, T., Theresia, C., \& Octavia, J. R. (2020). Analisis risiko produk Alat Pelindung Diri (APD) pencegah penularan COVID-19 untuk pekerja informal di Indonesia. Jurnal Rekayasa Sistem Industri, 9(2), 115-34. https://doi.org/10.26593/jrsi.v9i2.4002.115-134

Wati, N. M. N., Lestari, N. K. Y., Jayanti, D. M. A. D., \& Sudarma, N. (2020). Optimalisasi penggunaan Alat Perlindungan Diri (APD) pada masyarakat dalam rangka mencegah penularan virus COVID-19. Jurnal Empathy Pengabdian kepada Masyarakat, 1(1), 1-8. https://doi.org/10.37341/ jurnalempathy.v1i1.1 